\title{
The Importance of Indonesia's Nationalism Revitalization in the Globalization Era: A Historical Perspective
}

\author{
Singgih Tri Sulistiyono \\ Department of History, Faculty of Humanities, \\ Diponegoro University
}

\begin{abstract}
This article analyze on how nationalism which is product of Received: nineteenth century in Europe can be revitalized in facing the challenge of globalization. In Indonesian context, this issue is very urgent to be discussed considering the fact that the process of globalization tends to be confronted with the spirit of nationalism. Sometime nationalism is viewed as an obsolete tradition that should be revitalized. But there are still many people who believe that nationalism is still indispensable in the face of an increasing wave of globalization. However nationalism must be revitalized in order to be able to face the challenge of globalization. For this purpose, it is very interesting to strengthen the spirit of nationalism by

11 February 2018

Revised:

28 June 2018

Accepted:

2 July 2018

Corresponding author:

singgihtrisulistiyono@gmail.com revitalizing it for improving the nation competitiveness in facing the expansion of globalization. The questions are in what ways could nationalism be revitalized in order to improve the nation competitiveness to face the global competition? In addition, the fundamental question to be asked is why does Indonesian nationalism need to be revitalized? What is wrong with Indonesian nationalism? If Indonesian nationalism can be revitalized, how is it done? Those are set of questions that will be discussed in this paper.
\end{abstract}

Keywords: Nationalism; Globalization; Nationalism Revitalization; Nation Competitiveness; Historical Perspective.

\section{Introduction}

The title of this paper contains at the very least two immense issues which are Indonesia's nationalism revitalization and globalization. Those issues seem not directly associated. Literally, the term 'revitalization' can be defined as to reactivate or to make function again something that probably has expired. In the repertoire of anthropology, the concept of revitalization refers to an intended and organized movement as a conscious attempt performed by the members of some certain communities to build a more satisfying culture that can be easily woven into innovative configuration corresponding to the demand of time. It is strongly related to the nature of culture which has an internal mechanism to self-change adjusting to the encountered challenges.

Meanwhile, globalization is an international integrating process which happens due to the exchange of perspectives, products, ideas, and any other cultural aspects. Along with the development of information technology and transportation, the physical boundaries among nations become bias because they are penetrable with the advanced communication technology and global mechanism which compel every nation to open up in the global interaction. The 
improvement of information technology and transparency regime has been setting up free competition especially in the field of economy with a series of rules that are considered fair. ${ }^{1}$

The matter is what is the relation between revitalization effort toward nationalism related to globalization challenge and the effort of national quality improvement? In other words, can national quality in facing globalization be reached through nationalism revitalization? In what way nationalism revitalization can be treated as media to improve the quality of Indonesia? Besides, the fundamental query which should be questioned is why does Indonesian nationalism need revitalizing? If Indonesian nationalism can be revitalized, how is it executed? How come? Those are the sets of question which will be discussed in this paper.

\section{Nation's Actual Problem}

The two of the most problematic issues that are still faced by the Indonesian are dependency and inefficiency. Indonesia is still very dependent toward other nations whether it is recognized or not. It can be seen that Indonesia is still unable to fulfil its basic needs such as staple food and micro technology. This condition can change into a catastrophe if natural resources are sold out while we have not yet formed a strong structural foundation to become an independent and highly productive nation. At that time, the inability of the nation to fulfil basic human needs such as food becomes visible while in fact Indonesia has a great agriculture potential. ${ }^{2}$ This fits the first verse of Khalil Gibran's poem: "Pity the nation that... eats bread it does not harvest, and drinks wine it does not breed". ${ }^{3}$

Food crisis is only a little part of a bigger crisis encountered by Indonesia which is economy crisis started from the end of 1997. This crisis leads Indonesia into what is called economic decline. It was reflected by the piling state debt as well as private debt, rupiah's irrecoverable exchange rate toward US dollar as before the crisis, and the high rate of poverty. ${ }^{4}$ The unsolved economy crisis brings another crisis, such as political crisis which at that time contributed the fall of Soeharto regime. ${ }^{5}$ In addition to that, there are also leadership crisis, heroism crisis, trust crisis and moral crisis; as illustrated by Gibran "...whose statesman is a fox, whose philosopher is a juggler, and whose art is the art of patching and mimicking". A historian of Indonesian economics stated that in the Reformation Period, Indonesia suffered a

${ }^{1}$ Manfred B. Steger (Translator Heru Prasetia), Globalisme: Bangkitnya Ideologi Pasar (Globalism: The Rise of Market Ideology) (Yogyakarta: Lafadl, 2006), 38 - 44.

${ }^{2}$ On 15 January 2008 there was a demonstration by tempe and tofu manufacturer demanding the price of American-imported soybean is not increased. At that time, the price of soybean increased twice that the manufacturer of these product went bankrupt. See "Ribuan Perajin Tahu dan Tempe Demo di Istana" [thousands of tofu and tempe manufacturers run demonstration in the palace], in http://internasional.kompas.com /read/2008/01/14/10380239/ribuan.perajin.tahu.dan.tempe.demo.di.istana, retrieved on 9 June 2017.

${ }^{3}$ Kahlil Gibran's poem, "Bangsa Kasihan" (Pity the Nation) in http://www.sutrisnobudiharto.net/2015/09/ puisi-kahlil-gibran-bangsa-kasihan.html, retrieved on 7 June 2017.

${ }^{4}$ Howard Handelman, The Challengse of Third World Development, 3rd edition (New Jersey: Prentice Hall, 2003), 279. It has ever been predicted that in the late 2007 the amount of the state debt is approximately US $\$ 150$ billions or about 40 percent of the total GDP US\$ 364 billions. If it happens, 40 percent of annual state fund must be spent on debt interest. See"Utang Nominal Diproyeksikan Rp1.325 Triliun" (The Nominal Debt is Projected to be IDR 1.325 trillions, in http://suaramerdeka.com/ cybernews /harian/0707/11/nas4.htm, retrieved on $20^{\text {th }}$ January 2014.

${ }^{5}$ Robert Cribb, Historical Atlas of Indonesia (Honolulu: University of Hawaii Press, 2000), 188. 
total crisis. ${ }^{6}$ The recent heartbreaking phenomenon is the character damage of Indonesia reflected by many corruption acts and amoralities happening in the community. This "rotting process" will become a form of self-destruction if it is not anticipated immediately.

Aside from economic crisis, Indonesia is also facing various kinds of social and political conflict. In the community level where many economic problems arise, the atmosphere of openness and freedom even nearly tend to be anarchy. This is contra productive when democracy is deflected to be "democrazy" (in the context of demos who are crazy). It can be seen from television programs which broadcasts violence scenes in particular. Sentiments caused by race, religion, and community differences often become the conflict triggers. News and information that come from uncontrolled social media usage have contributed to the birth of persecution acts. Within the respect of situation, the community leaders are sometimes unable to control society emotion even taking part in creating the anarchy situation. This is similar as what Gibran said in his poem "... pity the nation that welcomes its new leader with trumpeting, and farewells him with hooting..."

Meanwhile, at the national level, many social and political conflicts are still considered as potential threats to disrupt national unity as what happened in Aceh, Maluku, Poso, West Papua, and so on. Some of the community organizations even demand for independence to detach from Republic of Indonesia. They want to establish their own nation like East Timor. The phenomena are still happening in West Papua. In addition to that, the emerging of radicalism in the name of religion also hazards the existence of Indonesia as a state. "Pity the nation that breaks into pieces and each piece thinks of itself as one nation," said Gibran.

There are indeed many efforts attempted by the government, yet they are done sporadically and not thoroughly executed. In the other time, it may explode again even become worse than before. The local community dissatisfaction toward central government frequently becomes the main reason of this problem. There is an accusation that central government improperly intervene local matters and draining out regional resources. ${ }^{7}$

Those issues escalated after Indonesia entered the era of democratization, transparency, and reformation. In this case, it can be considered that democratization is not always benefitted in a responsible way with respect to national unity. On the contrary, it is used to do things that potentially threat the unity. Therefore, the interest of national unity turns out to be an unimportant consideration. Meanwhile, the central government should realize that they observe things only from the central government point of view. They should consider the

\footnotetext{
${ }^{6}$ Jeroen Touwen, "The Economic History of Indonesia", in http://eh.net/ encyclopedia/ article/touwen.indonesia, retrieved on $9^{\text {th }}$ June 2017.

${ }^{7}$ The concept of "resource drain" has ever been mentioned by an economic historian Piere van der Eng. He stated that the resource does not only flow from outside Java to abroad but also flow from outside Java to Java. Therefore, the areas outside Java suffer double drain. He argues that during Netherland colonial period, the resource drain was actually immense in the form of wages and salaries for expatriats and capital profit invested in Indonesia. See Piere van der Eng, The "Colonial Drain" from Indonesia (Economic Division Working Paper, Research School of Pacific Studies, Australian National University, 1992). This argument is still debatable particularly about whether nowadays there is any resource drain from outside Java to Java or not. Scientific research concerned about this issue need to be done immediately. The outcome can be the foundation for equitable and interdependent economic development area planning as a system. See Singgih Tri Sulistiyono, "Maritime Dynamics of Nusantara: Historical Reflections on Indonesian Economic Expansion and Integration as Maritime State" (Keynote Speech delivered on the International Seminar on The Maritime Dynamics from the Perspective of Literature and History (Semarang: Faculty of Letters Diponegoro University, $15^{\text {th }}$ December 2007)
} 
interest of local interests to live in prosperity. If this matter is ignored, it may trigger local communities to think about the relevancy of being ruled by the central government when there is no life improvement. The central government in Jakarta needs to leave the mindset they used to have. One of the reasons why the whole elements of Netherland East Indies at that time accepted to unite under the newly-formed Indonesia is the same fate they had suffered through. In this context, there was "mutual prosperity and welfare" spirit that must be held firmly by the central government. The major motive of multiple anti-Indonesia movements is concerned strongly about justice and welfare issues that they cannot experience with the rest of other communities like what happened in the colonial era.

In this case, Indonesian had better realize that the relation between central government and local government should be based on certain agreements corresponding to the concept of nation unity. Law enforcement must be assured to oversee the agreement. Nevertheless, government need to be thoughtful and introspect itself to avoid any kind of power abuse and corruption act which nowadays still become a perturbing problem. If the government does not do self-introspect, then the community who will introspect them at some point. The outcome of the crises is the arising conflicts suffocating Indonesia which makes its dignity decrease in the eye of international world.

The decreasing quality of the society's life is surely does not come along with the notion of the founding fathers which is society's life full of justice and prosperity, both materially and spiritually, which is based on Pancasila (The Five Principles) and 1945 Constitution of Indonesia (UUD 1945). It must be in line with the atmosphere of independence, friendliness, well-order, and dynamism. However, the manifestation of those notions becomes more out of reach. They are rarely remarked by the today's nation leaders. So are Pancasila and UUD 1945. The Republic of Indonesia starts to be objected, and independence becomes an illusion. Moreover, the unity bond is getting fragile while people power becoming out of boundaries. In the end, safety and security become confined and the self-regard tumbles in the eye of the international world.

\section{Nationalism: Can it solve the problem?}

Since the late $20^{\text {th }}$ century until the early $21^{\text {st }}$ century, Indonesian nationalism encounters difficult challenges. On one hand, globalization process and free trade expansion have made as if nation-state of Indonesia becomes powerless. The state power is lessening and many state authorities are taken by the market. The state is only viewed as the referee, even worse, the referee who is coopted by the market power. Consequently, the referee is not neutral and has tendency to the market and money.

The regime of free trade in the context of globalization has created a condition as if national borders are irrelevant. The economic power supported by the improved information and communication technology has made a mindset that nations are not significant anymore. Even there has been a misconception about 'the end of nation-state'. The states are only viewed as a bother, money wasting, corruptor hollow, capitalism cradle, and many more which make the right of the society offended. If the nation cannot give prosperity and justice yet it abuses the power to overrule the society, will the spirit of nationalism grow? Instead of 
using it to solve the problem - in that kind of circumstance - nationalism will suffer internal decay.

Besides, the declining quality of nationalism can also come from the internal dynamism of Indonesia. Indonesia as a nation which is a supra-ethnic construction was born by agreements in the historical process. This ethnical problem will appear again when the pillars of the nation cannot provide prosperity, justice, pride, and problem solver. Today when that supra-ethnic pillar which is Indonesia nation-state is decaying, the spirit of nationalism is also crumbling. Then, it is hard to expect that the nation problem could be solved by nationalism because the nationalism itself is problematic.

If studied historically, in the early days of its growth, Indonesian nationalism has been proven to contribute significantly to the solution of national problems, especially in the process of strengthening the sense of Indonesianness as a new nation, and in order to expel the invaders. As it is known, the period of the emergence of national movement appeared along with the peak of the development of colonial society, which is the product of Dutch colonialism in Indonesia. In the colonial society, the position and role of Indonesian society were marginalized by the colonialists. In various ways, the colonialists controlled the lives of Indonesians: from intimidation, pitting, to invasion and annexation. Even the colonial power seeked to perpetuate the seizure by creating the rule of law they made, so as if their presence had a basis of legality. In this way, they tried to create a colonial society with the spirit of apartheid. The racial base is used to create colonial laws. For example, in Article 109 of the Government Regulation (Regeering Reglement) of 1854, there was a distinction between the classes of society: the European class and the likened to Europe on one hand, and the Natives on the other. In the beginning, the Indigenous category also included immigrant people from Asia such as Chinese, Indians, Arabs, Japanese, and so on. But then they were separated into their own group with the title of the Eastern Foreigners who occupied the second class after the European class. Thus, ethnic and racial criteria formed the basis of the legal structure of colonial society. ${ }^{8}$ So at that time, the people of Indonesia were facing structural injustice deliberately created by colonial rulers who put the indigenous people in the most despicable position in the structure of colonial society. Culturally, this kind of policy had made indigenous people suffer from minderwardigheids complex, a kind of chronic low self syndrome.

A rather conspicuous historical environment, which influenced the development and appearance of the spirit of nationalism, is the strengthening process of colonial state. At that time, a lot of national movement organizations were facing the power of the colonial state. Both the people and the government's positions tended to be face-to-face frontally in colonial society; therefore, conflicts would be something latent in the relationship between the state and the people. The last period of colonialism saw how the colonial power tried to strengthen the colonial states, thus weakening the colonized people. As it is known, the strengthening process of colonial states started from the nineteenth century when the bureaucratization process of colonial states happened, where both the bureaucracy of Europe

${ }^{8}$ See V.J.H. Houben, 'Java in the 19th Century: Consolidation of A Territorial State', dalam: Howard Dick, The Emergence of A National Economy: An Economic History of Indonesia, 1800-2000 (Leiden: KITLV Press, 2002), 61 . 
(Binenlandsbestuur) and indigenous (Inlandsbestuur) became the execution machine of central government's policies in Batavia (Governor-general) or Minister of Colonial Affairs in Netherlands.

The number of bureaucrats that kept increasing, especially in Java, shows how the colonial state had become stronger. Even though the number of high officials between 1825 and 1890 did not show significant increase, it happened at the level of intermediary officials (the level of redisen and controlleur) from 73 people in 1825 to 190 people in 1890 . They had a very central position in colonial bureaucracy. These officials were the ones that started the relationship with indigenous bureaucracy directly (the regents and the devices below). They were the ones that forced the indigenous officials to follow the colonial policies. The colonial power was also supported by KNIL (Koninklijke Nederlands-Indisch Leger), a very strong group of soldiers. They had 10.000 personnels in 1820, but it increased to 30.000 personnels in 1875. KNIL became powerful guards for the running of colonial bureaucracy. ${ }^{9}$

The strengthened colonial state went hand in hand with the economic expansion done by the Dutch. It could even be said that the strengthening of the colonial state itself was sought to make economy expansion possible. If there was a development where the state gave freedom to both people/private, in the colony, the colonial government applied an interventionist policy to both political and economic fields. In this connection, Java for example, was placed in a position as a wingewest (province-like) for the mother country. The function of the colonized country was only as a dairy cow, or as a cork that kept the Netherlands still afloat on the sea.

The description above gives a clear picture that the colonized people faced multidimensional suffering: culturally, politically handled, and economically exploited. The emergence of Ethical Politics in the early twentieth century that rhetorically intended to 'repay the favor' of the colonized people and its prosperity may in fact serve as a tool for the colonial state to reaffirm its power over the people whom during the second half of the nineteenth century were guided by private investors. Within the framework of this Ethical Policy, it was the state that determined the concept of economic prosperity and the application of political welfare concepts by establishing a political perception that the people as kawulo (ordinary people) and government as gusti (nobility) were authorized to become pangreh pradja (who governed the state). Thus, although this Ethical Policy might economically increased the welfare of society politically, the position of the people became weaker. Moreover, ethical rhetoric in Java was ludicrously accompanied by brutal expansion and conquest of regions in the Outer Islands such as Lombok, Bone, Aceh, Sram, and so on. ${ }^{10}$

The national movement based on the spirit of nationalism at the time was not the only form of resistance to colonialism in Indonesia. The colonial antecedent itself was already part of the tradition of resistance in Indonesian history. It can be seen from the people's struggle against colonialism both before and after XX century. During the nineteenth century there

${ }^{9}$ Houben, 'Java in the 19th Century', 60.

${ }^{10}$ See J. Th. Lindblad, 'The Outer Islands in the 19th Century: Contest for Periphery', dalam: Howard Dick dkk, The Emergence, 98. See also C. Lulofs, Onze Politiek tegenover de Buitenbezittingen (Batavia: Van Dorp, 1908), 21-70. See also J.Th. Lindblad, 'De Opkomst van de Buitengewesten', in: A.H.P. Clemens \& J.Th. Linblad (eds), Het belang van de Buitengesten: Economische Expansie en koloniale Staatsvorming in de Buitengewesten van Nederlandsch-Indië 1870-1942 (Amsterdam: NEHA, 1989), 1-6. 
were many popular resistances to the Dutch colonialism in large scale such as the Pattimura War, Diponegoro War, Padri War, Aceh War, and so on. Otherwise in a small scale to free the shackles of colonization, eradicate discriminatory treatment and deprivation of prosperity by the rulers colonial. ${ }^{11}$ It should be emphasized here that the sense of Indonesian nationalism that became the driving force for the emergence of a new national movement took place in twentieth century. Nationalism emerged as part of a process of intellectual discourse as a logical consequence of the development of modern education since the end of the nineteenth century.

There are several prominent features of the emergence of national movements in Indonesia. First, there are anti-colonial feelings and sometimes exaggerated xenophobia. It might even be that this trait encouraged the acceleration of the formation of nationalism. Second, the role of the immigrants was enormous in fostering national consciousness. At first nationalism that emerged in the Dutch East Indies was overseas nationalism that came from the interactions between people from Ambon, Minahasa, Sumatra, Java, etc.

Third, the character of urbanity is very prominent in the process of nation formation. This is due to the fact that social interactions between ethnic and different social groups were prevalent in large cities from pre-colonial times as centers of ethnic and social group meetings for business. From this side, the cities serve as a 'melting pot' for various social elements, allowing them to know each other, interact, and make agreements to build a life as a community of nation. So it seems that foreign occupation and consciousness as colonized peoples has driven a national resurgence. In the colonies, colonialism gave birth to nationalism. It was nationalism that in turn succeeded in expelling foreign colonialism. So at that time, nationalism could be used as a medium to overcome the problems faced by the Indonesian nation in order to expel colonials in order to gain independence. Of course, the spirit of nationalism can also be used to cherish the independence.

\section{Revitalization of Indonesian Nationalism}

In the previous section, it has been explained how nationalism has a significant contribution in solving the problems of the nation community in the early stages of the course of modern Indonesian history. ${ }^{12}$ If the struggle of the Indonesian nation during the colonial period is to expel the invaders to achieve national independence, then the struggle of the Indonesian nation after finally achieving independence is to realize unity, sovereignty, and justice and prosperity as embodied in the Preamble of the 1945 Constitution, namely: “... Indonesia who are independent, united, sovereign, just and prosperous". If during the colonial period of Indonesian nationalism could be a driving force and a source of inspiration so that the Indonesian nation was able to achieve independence and expel foreign invaders, then the question is why Indonesian nationalism became weak and no longer able to maintain 'independence' and sovereignty of various forms of 'new colonization '. Why is Indonesian

\footnotetext{
${ }^{11}$ About several little-scale movements in the form of social movement see for example Sartono Kartodirdjo, Protest Movements in Rural Java (Oxford, New York, Jakarta, Kuala Lumpur: Oxford University Press, 1978).

${ }^{12}$ Singgih Tri Sulistiyono, “Nasionalisme, Negara-Bangsa, dan Integrasi Nasional: Masih Perlukah?", Jurnal Sejarah Citra Lekha 3 (1) 2018, 1-12.
} 
nationalism stumbling in the face of the threat of disintegration, and wobbled in achieving the national ideal of realizing a just and prosperous society? Why is Indonesian nationalism now no longer able to be a force and a driver to achieve national goals? If that is the case, then it is necessary to revitalize Indonesian nationalism. The next question is in what way is the revitalization of Indonesian nationalism done?

\section{The Decline Signal of Nationalism}

The decline signal of people's welfare quality as a nation has appeared since the eighties. Various signals such as 'the decline of nationalism and patriotism', 'the decline of heroism', 'disintegration threat', or 'the decline of national consciousness' had started to be worrisome at that time. Ironically, those worries appeared amidst the New Order government's attempt to push P4 (Guidelines Appreciation and Practice of Pancasila), promote PSPB subject (History Education of Nation's Struggle), and economic condition that was in a booming period.

Perhaps it still sticks in Indonesian people's minds how President Soeharto, in his last years of presidency, wanted to create a National Awakening II where various analysis appeared regarding that correlation. First, President Soeharto, at that time, wanted to rejuvenate the spirit of nationalism that had been deterred due to apathism symptoms and frustrasion as a result of economic domination and cultural hegemony by groups of people that were close to power. In hope of gaining a stronger support from all elements of the nation, Soeharto launched the National Awakening II. Second, the plan implicitly stated Soeharto's desire to build an image like dr. Sutomo's who was one of the pioneers of National Awakening at the early nineteenth century.

Whatever happened, whatever words had been said by President Soeharto at that time had only become a rethoric that almost never got through to people's substances. The echoes might have only vibrated within the bureaucracy officals, but even that, they had no meanings; that issue never reflected a significant awakening within the nation. The question is, why the awakening call did not have any significant effect towards the nation? President Soeharto was even got impeached embarassingly by the people. Is there something wrong with people's way of thinking today that makes it hard for them to do a national awakening maneuver (a la Soeharto, at least) as a way to do historical leaps to reach a development that is as spectacular as the national awakening development that happened at the early nineteenth century.

The same thing happens to President Susilo Bambang Yudhoyono (SBY) who attempted to push national character building. Mostly, the attempts were implemented through education. In his speech during the celebration of National Education Day in May $2^{\text {nd }} 2010$, President SBY stated that education in Indonesia has two main purposes: to transfer science and technology, and strong national character building. He also said that education should not forget character building. Therefore, through Minister of National Education, President would launch 'Character Building Program'. What had been planned by the President is not without reasons. There are a number of people who are worried by the phenomenon that reflects the decline of nationalism and patriotism spirit, and the loss of character as a nation. 


\section{Important Points for Nationalism Revitalization}

There are several important points in the life of the nation and the state that needs to be revitalized in order to enable the functioning of nationalism as a driving force and a source of inspiration in achieving common goals as an independent nation, united, sovereign, just and prosperous. President Sukarno once formulated this national goal as a trilogy, namely: politically independent, economically prosperous, and culturally dignified. The important points are:

\section{The Awareness of Getting Colonized}

Back to the basic question: Why did the first National Awakening succeeded in delivering the formation of Indonesia to its peak (Proclamation on $17^{\text {th }}$ August 1945), while the second National Awakening that wanted to achieve the proclamation's purposes - a just and prosperous society - did not get welcomed? The answer is, the national movement organizations at that time fit with the people's conditions and they could articulate and 'realize' people's ideals. As Anderson (2011) argued that the paradox of postcolonial states pursuing internal and external policies remarkably which focuse on the distinct, longstanding, institutional interests of the state-qua-state. ${ }^{13}$

The actual condition of Indonesian society as colonized society at that time was a society that was politically imprisoned, economically exploited and culturally insulted. The very basic question really lies in the fact that most societies accept it as the fate (destiny of destiny) which is outlined by God. This unconsciousness became a fundamental problem and therefore this issue became the main task for national movement organizations to raise awareness of most people. This had been very well formulated by Sukarno by pumping the awareness that in ancient times the Indonesian nation had triumphed, now as a despised colony, and a glorious future would be achieved by struggling against colonialism. Resistance must be raised between the 'here' (Indonesia) and the 'there' (Dutch) parties. ${ }^{14}$

Thus the ingenuity to formulate actual problems and sharpness articulated the people's desires and the ability and courage to realize these ideals was the key to the success of the national movement. Likewise, what is equally important is to raise public awareness that they were in a despicable state as colonized people. Only consciousness as a colonized society that would give the spirit for independence. In addition, one of the basic attitudes possessed by the figures and organizations of the national movement at the time was an independent attitude in the struggle and realization of ideals. That is, since the early period, they had realized that independence as a nation was something that would not come from 'there' but must be taken by 'here'.

What about the second National Awakening now and in the future? Are there enough reasons to say that this awakening does not get welcomed because the structural problems faced by Indonesian people then (as colonized people) and now (as free people) are different? Is

\footnotetext{
${ }^{13}$ Bennedict Anderson, “Old State, New Society: Indonesia's New Order in Comparative Historical Perspective", Journal of Asian Studies 42 (May 1983): 477.

${ }^{14}$ See Bob Hering, Soekarno: Founding Father of Indonesia 1901-1945 (Leiden: KITLV Press, 2000), 145.
} 
national awakening still needed? If needed, what for? Are not Indonesian people have been freed?

The second National Awakening, or whatever it is named, will not surpass the independent people stage in its true definition. A just and prosperous society that has been idealized can only be achieved through independence. The independence itself, as mandated by the opening of UUD 1945 is only a gate, a golden bridge to start a fight in order to achieve a just and prosperous society.

Seeing failure after failure experienced by the Indonesian nation so far, hesitation needs to be asked: have the people of Indonesia been really independent? As a 'nation', indeed Indonesia had proclaimed its independence in 1945, but the question is whether it is truly free indeed? Whether Indonesia as a nation is still colonized by other means, such as economic colonization (with impact: mounting debts and inevitable inhalation of wealth), political colonization with a lack of government independence in deciding broad-based political policies. In fact, it seems that the people have not yet received true freedom because they are almost always faced with a ruler who is unable to give people freedom in a broad sense. What is most wretched is: they are still colonized but already feeling free or accepting the occupation as a fate. If that happens then the spirit to fight for freedom will not rise, because it already feels free, prosperous, just, rich, and so forth. Thus, the key to arousing the people to mobilize the spirit of national awakening is to realize that this nation is still in a colonized condition so it must struggle to free itself from poverty, ignorance, exploitation, injustice, and so on. In addition there needs to be an awareness that this nation is in great danger both from the economic, political, ideological, and cultural aspects. If fundamental ways not immediately taken, then it is not impossible if the national awakening that we hope will actually result in 'national bankruptcy'. That awareness can be done by anyone (school, political party, government agency, etc.) and through any media. In this case the role of learning history in school becomes very important for it can function as a 'liberator' way of thinking of the younger generation in addressing the problems of the nation in the present and the future.

\section{Independence}

One of the keys to the success of National Awakening I is the independence of national movement organizations and their leaders so that they were able to develop thoughts and actions that are appropriate to their own ideals in order to improve the lives of their people. The situation had forced most of them to survive and develop independently. It was almost impossible for them to 'ask for help' to the Dutch colonial government that they would break. In various ways, the national movement organizations collected all kinds of resources available to carry out their actions. Indeed, Indeed, there were people that worked together with the colonial government, but it was often a strategy to avoid confrontation with the colonial government. Their intentions remained intentional to the interests of the various elements of indigenous society. Thus the various organizations of the national movement at that time were relatively independent and not dependant or relatively free from the intervention of the colonial government to which it opposed.

Of course at this time the government of the Republic of Indonesia is not an enemy that must be liquidated. In this case a synergy between the interests and power of the people with 
the government must be built. Independence must be built at the individual, community and government levels so that it does not depend much on foreign debt. Experience has given the lesson that it is from this debt that economic, political and cultural independence will be deprived. It is a common knowledge that the forces of neoliberalism will perpetuate their colonization through the entanglement of debt and the subsistence of the dependence of the power of capitalism. Thus the independence that must be built within the framework of National Awakening I is to escape from debt bondage and dependence to foreign parties. What must be done immediately is to implement the 'independence revolution'.

Of course it is not done by stealing but by way of economic development based on production with always put forward invention and innovation. Educational institutions, nongovernmental organizations, and governments should be prepared for this effort. The habit of lulling people with imported goods should be stopped.

\section{Reorientation from Ethno-nation to Nation-State}

In the earlier part, it has been explained that in the beginning of the twentieth century, there has been an evolution of ethno-nation spirit to nation-states culminating in an agreement to become a nation with the Youth Oath of 1928, and it is realized in 1945. The national binding factor at that time is the same goal which is to be independent politically, prosper economically with cultural dignity as often stated by Bung Karno. In addition, the feeling as a nation which is being colonized by the Dutch in the Dutch East Indies is also one of the impetus for the development of the feeling as a nation. In this case, all elements in society expect organizations and figures of national movement to realize their goals and expectations as a nation community. Those goals and expectations knit the various ethnic groups into one nation, the Indonesian nation.

What matters now is that at this time when National Awakening II and 100 years of National Awakening and so on are declared, it is even a reversal of the nasionalism development. Based on the symptoms during the last decade, it is clearly seen that there is evolutionary process from the nation-state to the ethno-nation. The nation state is beginning to be threatened for fragmentation into an ethnic country. This process happened in many places, such as the former Soviet Union, Yugoslavia, and so on.

Since the Indonesian nationalist protagonist factor is primarily derived from the same goal, ideals, and fate (history), if there is a reverse process, then it is necessary to re-examine the effectiveness of the protagonist's factors. Question which can be asked is why the goals, ideals and similarities of fate are no longer able to bind Indonesian-ness? Is it due to the changed way of thinking of the Indonesian people or of the goals, ideals and feelings of the changed fate? For example in terms of feelings of destiny, many people feel that now the fate of people / officials in Jakarta is different from the fate of people in Aceh, Maluku, or Papua. Many people see Jakarta as having a better fate than in the outside of Java. Thus, this can certainly be seen as a betrayal of the goals and ideals of a prosperous and equitable society. Thus, it is the duty of the government to develop economic integration so that the gaps both vertically (rich-poor) and horizontally (wealthy areas-poor areas) can be eliminated. This effort is further supported by political and cultural integration through historical and civic education to enlighten historical and cultural roots as a nation and the development of fair cross-cultural 
communication and the adoption of tolerance. By that way, the crisis of pride as Indonesia nation can be rebuilt.

\section{Making the Same Fate}

What has become a problem is that the phenomenon of regional resistance and separatist movements in various regions is often only seen from a 'central' perspective which in this case is the Indonesian government in Jakarta. Every form of resistance and separatism is seen as a manifestation of disloyalty and denial toward the 'noble consensus' of founding fathers who have pioneered the founding of the state of Republic of Indonesia. The logic of central government power is often based on the premise that blackout against every resistance and regional separatism is a mission to uphold the 'noble consensus' to uphold the state of Republic of Indonesia. Therefore, any repressive action of the central government gets justified from the premise of such thinking. In repressive conduct, it is almost unheard of that the central government is introspective to answer the question of why resistance and the separatist movement are happened.

It is very interesting to see the contradiction of local and national perspectives or between region and center in relation to the question of how the state of Indonesia is maintained. The central government always assume that the consensus processes which led to the proclamation of independence on 17 August 1945 constitute a final consensus which is a compulsion to be maintained. The agreement is believed to be partly motivated by the feeling of having the same fate as a colonized society who wants an independent, unified, sovereign, and prosperous state as envisaged in the 1945 Constitution. It is imagined that at that time, the country to be built was a state which is able and willing to protect the whole nation, the whole spill of blood, create prosperity and common prosperity, and educate the life of the nation. It has become a kind of social contract. Often the government's repressive actions are based on only part of that spirit, which is to defend to the last drop of the consesnsus of 1945, without wanting to see whether the intended functioning of the state has proceeded in accordance with that consensus and expectation. Yet, from the perspective of the regions, the function and purpose of the state of Republic of Indonesia itself are more important, not the deal. Perhaps there are often questions about the advantages of joining Indonesia if it has to be exploited and destitute. Would not it be better to stand alone or join a more prosperous and fair country? So it is the time for the central government to approach welfare and prosperity and justice rather than repressive approaches both politically and militarily.

There are some changes in the society which are not all caught by the elite government. The feeling of 'Indonesian-ness' and nationalism can no longer be raised through historical romanticism, for example: by declaring that 'we are a nation with same fate as a colonized nation' as it had often been buzzed by nationalist figures, like Soekarno. Indeed, the colonization phenomenon is generally happened by the Indonesian nation although it is sure that not all of social group in archipelago felt colonized at that time. What is even more important is that the feeling of the same fate as a colonized nation can be contextual. Perhaps, in the time after the war, the feeling of Indonesianism could be developed only by that kind of historical romanticism, but by this time when it has changed, the generation also changes so 
that the historical romanticism can no longer be used to perpetuate the feeling of 'Indonesianess'. There are many praxis aspects which become important consideration. The important consideration is how Republic of Indonesia once treated as a result of noble consensus which is jointly defended can provide proseperity, welfare, justice, and pride to every citizen. This desire is a very natural thing. As a nation which had felt the wretched colonialism for a long time, they imagine that Indonesia, as the replacement of the colonial state, can provide economic prosperity, political nationality, dignity, and also cultural pride which had been buzzed by Bung Karno with his Trilogy.

\section{Socio-Cultural Approach}

Another actual problematic over the past decade are the rise of regional sentiments, the issue of regional sons, ethnicity, and religious conflict which all of them seem to be antecedent to the indonesian formation process. During this reformation period, the conflict cases consisting of conflict between social, ethnic, religious groups and the ethnic cleansing indication. Of course, one can argue deductively that such social phenomenon is hard to occur if the justice, welfare, and prosperity can be felt by the society, and the sense of Indonesian-ness is owned by all elements of Indonesian society.

Thus, there are some actul issues which are crucial faced by Indonesian society, for example the establishment of Republic of Indonesia in 1945 as a formal political entity has not been totally followed by the formation process into Indonesian communities and nations so that the sense of Indonesian-ness still becomes a problem. Some various incidents of interethnic conflict, resistance and separatist movements show that the sense of Indonesian-ness (if it has been existed) in certain situations and/or certain interests is still sacrificed for the benefit of ethnicity, locality, primordialism and various other interests. Moreover, throughout the history of Indonesia, the central government approach to overcome the national and sociocultural disintegration through emphasizing more on security and political approach. The security and repression approach will cause politically nation disintegration and socioculturally 'dis-indonesian-ness'. In this case, it is the time for the government to emphasize the welfare and justice approach in order to resolve the conflicts and disintegration threat and the 'disindonesianization' phenomenon.

Likewise, socio-cultural approach must replace politically and military emphasis and indoctrination in internalizing the feeling of Indonesian-ness. In this case, studying history in schools and in other formal educational institutions is very important. The problem is what kind of historical learning materials which are effectively able to cultivate the feeling of Indonesian-ness because the students at school have learned history lesson during this time. Broadly speaking, the historical learning materials for developing Indonesian flavors are materials which describe 'process to be Indonesia'. It is a long inevitably historical process which 'requires' some various social and ethnic groups to become Indonesia, not another nation.

Thus, the 'process to be Indonesia' is not started since the time of national movement, and it is also not started since the proclamation of 17 August 1945. The narrative and explanation of 'process to be Indonesia' needs to start from ancient times until the present 
period. Decolonization 17 August 1945 is just one of the most important things in the 'process to be Indonesia' which is the establishment of Republic of Indonesia. That event is just one point from an evolutionary process which is called 'a process to be Indonesian' (as community and nation). It is undeniable that colonialism greatly colored the 'process to be Indonesia', especially when the Western colonialists devide the physical and political boundaries who will become the subjects of the Dutch East Indies (then it becomes the color of the Indonesian state), who becomes the subject of British Malaysia (Then it becomes Malaysian citizen), and so on. ${ }^{15}$ Once again, the proclamation of independence is only a small part of the evolutionary process of being Indonesia.

Because of the formation process of Indonesian-ness, it is not only started since 1945 and even since twentieth century, but it is started before that time so that the evocation of the spirit of Indonesian-ness through history needs to be shown through long description and explanation of history.

\section{Conclusion}

From the explanation above, some important issues can be infered. One of them are about the Indonesian spirit of nationalism has significantly contributed in the Indonesian formation itself and in the struggle to expel the foreign invanders from Indonesia. In this time, Indonesia is facing many problems both from external forces as a result of globalization and expansion of the free market system and internal dynamics in the political, economic, social and cultural fields. Pre-war nationalism (vor de oorlog) is not effective anymore in solving all the big problems faced by Indonesia recent time.

The revitalization of Indonesian nationalism is needed in order to be the driving force and inspirational source for Indonesia to solve some various problems which are not resolved in this time. The important points in implementing nationalism revitalization are includes colonization awareness, independence, reorientation from ethno nation to nation state, creating fate equality, and socio-cultural approach in solving some various national disintegration problems.

\section{References}

Anderson, Bennedict, “Old State, New Society: Indonesia's New Order in Comparative Historical Perspective." Journal of Asian Studies 42 (May 1983): 477-496.

Cribb, Robert Historical Atlas of Indonesia. Honolulu: University of Hawaii Press, 2000.

Handelman, Howard. The Challengse of Third World Development, 3rd Edition. New Jersey: Prentice Hall, 2003.

Henley, David. Nationalism and Regionalism in a Colonial Context: Minahasa in the Dutch East Indies. Leiden: KITLV Press, 1996.

Hering, Bob. Soekarno: Founding Father of Indonesia 1901-1945. Leiden: KITLV Press, 2000.

\footnotetext{
${ }^{15}$ According to Ricklefs, The colonial government of Netherland did not create Indonesia, but they only set the area borderlines, see M.C. Ricklefs, A history of modern Indonesia since ca. 1300 (London: Macmillan, 1981), 138. David Henley stated that by setting the borderlines, the government of East Indies had determined which ones are the Indonesians and which are not see David. Henley, Nationalism and regionalism in a colonial context: Minahasa in the Dutch East Indies (Leiden: KITLV Press, 1996), 5.
} 
Houben, V.J.H. 'Java in the 19th Century: Consolidation of A Territorial State', in Howard Dick, The Emergence of A National Economy: An Economic History of Indonesia, 18002000. Leiden: KITLV Press, 2002.

Kartodirdjo, Sartono. Protest Movements in Rural Jawa. Oxford, New York, Jakarta, Kuala Lumpur: Oxford University Press, 1978.

Lindblad, J. Th. 'The Outer Islands in the 19th Century: Contest for Periphery', in Howard Dick, The Emergence, of A National Economy: An Economic History of Indonesia, 18002000. Leiden: KITLV Press, 2002.

Lindblad, J.Th. 'De Opkomst van de Buitengewesten', in: A.H.P. Clemens \& J.Th. Linblad (eds), Het belang van de Buitengesten: Economische Expansie en koloniale Staatsvorming in de Buitengewesten van Nederlandsch-Indië 1870-1942. Amsterdam: NEHA, 1989.

Lulofs, C. Onze. Politiek Tegenover de Buitenbezittingen. Batavia: Van Dorp, 1908.

Ricklefs, M. C. A History of Modern Indonesia since ca. 1300. London: Macmillan, 1981.

Steger, Manfred B. Trans Heru Prasetia. Globalisme: Bangkitnya Ideologi Pasar (Globalism: The Rise of Market Ideology). Yogyakarta: Lafadl, 2006.

Sulistiyono, Singgih Tri. "Maritime Dynamics of Nusantara: Historical Reflections on Indonesian Economic Expansion and Integration as Maritime State". Keynote Speech delivered on the International Seminar on The Maritime Dynamics from the Perspective of Literature and History, Semarang: Faculty of Letters Diponegoro University, $15^{\text {th }}$ December 2007.

Sulistiyono, Singgih Tri. “Nasionalisme, Negara-Bangsa, dan Integrasi Nasional: Masih Perlukah?" Jurnal Sejarah Citra Lekha 3, no. 1 (2018).

Touwen, Jeroen, "The Economic History of Indonesia", in http://eh.net/ encyclopedia/ article/touwen.indonesia, retrieved on 9 June 2017.

van der Eng, Pierre. The "Colonial Drain" from Indonesia. Economic Division Working Paper, Research School of Pacific Studies, Australian National University, 1992.

"Ribuan Perajin Tahu dan Tempe Demo di Istana" [Thousands of tofu and tempe manufacturers run demonstration in the Palace], in: http://internasional.kompas.com/read/2008/01/14/10380239/ ribuan.perajin.tahu.dan.tempe.demo.di.istana, retrieved on 9 June 2017.

"Bangsa Kasihan" [Pity nation] in http://www.sutrisnobudiharto.net/2015/09/puisi-kahlilgibran-bangsa-kasihan.html, retrieved on 7 June 2017.

"Utang Nominal Diproyeksikan Rp1.325 Triliun" (The Nominal Debt is Projected to be IDR 1.325 trillions, in: http://suaramerdeka.com/cybernews/harian/0707/11/nas4.htm, retrieved on $20^{\text {th }}$ January 2014. 